IZA DP No. 8878

The Role of Trade and Offshoring in the Determination of Child Labour

Alessandro Cigno

Giorgia Giovannetti

Laura Sabani

February 2015

Forschungsinstitut zur Zukunft der Arbeit Institute for the Study of Labor 


\title{
The Role of Trade and Offshoring in the Determination of Child Labour
}

\author{
Alessandro Cigno \\ University of Florence \\ and IZA \\ Giorgia Giovannetti \\ University of Florence \\ Laura Sabani \\ University of Florence
}

\section{Discussion Paper No. 8878 \\ February 2015}

\author{
IZA \\ P.O. Box 7240 \\ 53072 Bonn \\ Germany \\ Phone: +49-228-3894-0 \\ Fax: +49-228-3894-180 \\ E-mail: iza@iza.org
}

Any opinions expressed here are those of the author(s) and not those of IZA. Research published in this series may include views on policy, but the institute itself takes no institutional policy positions. The IZA research network is committed to the IZA Guiding Principles of Research Integrity.

The Institute for the Study of Labor (IZA) in Bonn is a local and virtual international research center and a place of communication between science, politics and business. IZA is an independent nonprofit organization supported by Deutsche Post Foundation. The center is associated with the University of Bonn and offers a stimulating research environment through its international network, workshops and conferences, data service, project support, research visits and doctoral program. IZA engages in (i) original and internationally competitive research in all fields of labor economics, (ii) development of policy concepts, and (iii) dissemination of research results and concepts to the interested public.

IZA Discussion Papers often represent preliminary work and are circulated to encourage discussion. Citation of such a paper should account for its provisional character. A revised version may be available directly from the author. 
IZA Discussion Paper No. 8878

February 2015

\section{ABSTRACT}

\section{The Role of Trade and Offshoring in the Determination of Child Labour}

Incorporating family decisions in a two-period-model of the world economy, we show that trade liberalization may reduce child labour in developing countries where the initial share of skilled workers in the adult workforce - though not as large as in developed countries - is nonetheless large enough to attract skill-intensive FDI from the latter. If the production activities so relocated are more skill-intensive than those carried out in the destination countries before liberalization, that will in fact tend to offset the downwards pressure on the ratio of skilled to unskilled wage rates (Stolper-Samuelson effect), and thus on the incentive for parents to invest in their children's education, associated with international specialization. The hypothesis is not rejected by the data, and thus helps to explain why child labour has not risen in all developing countries, but risen in some and fallen in others.

JEL Classification: D13, D33, F16, J13, J24

Keywords: trade barriers, FDI, skill endowment, skill premium, school enrolment, child labour

Corresponding author:

Alessandro Cigno

Department of Economics and Management

University of Florence

Via delle Pandette 9 (D6-256)

50127 Firenze

Italy

E-mail: cigno@unifi.it 


\section{Introduction}

The past decade has witnessed an increase in international trade, and in the relocation of production activities across national borders ("offshoring"). Over the same period, child labour has fallen in some parts of the world, and risen in others. The present paper seeks to find a nexus between these two phenomena. A stream of economic literature tracing its origins to the theoretical work of Kaushik Basu views child labour as a direct consequence of extreme poverty. According to this line of reasoning, if parental income is sufficient to keep the entire family above subsistence level, children will not work. If it falls below that level, however, all the children in the family will be made to work. For an overview of the theory, see Basu and Van (1998). For empirical work along these lines, see Edmonds (2005), and Edmonds and Pavcnik (2006). Another stream of economic literature, associated with the work of Alessandro Cigno, views child labour as the outcome of parental optimization. For an overview of theory and empirical evidence, see Cigno and Rosati (2005). According to this other line of reasoning, decisions concerning the allocation of a child's time rest on a comparison of the immediate benefits of child labour with the expected benefits and costs of education. ${ }^{1}$ The two approaches are not irreconcilable. If parents cannot borrow, current expenditure cannot in fact exceed current income. In families where this constraint is binding, children will then work even if the expected return to education is higher than the return to labour. Without credit market imperfections, therefore, the allocation of the children's time between work and study would be the outcome of a portfolio decision, and thus independent of parental income. Given market imperfections, however, the decision is subject to a liquidity constraint (see Ranjan 2001, Dehejia and Gatti 2005, and Beegle et al. 2006). For families close to the breadline, the allocation will then depend essentially on parental income. As family income rises, however, the link between child labour and parental income becomes progressively weaker and eventually disappears. How does trade and offshoring come into the picture?

Jafarey and Lahiri (2002) construct a model of a small open economy that produces and exports a good with a low skill (high child labour) content. In this model, parents choose how much to invest in their children's education taking the price of the good, the child wage rate and the interest rate as given. The authors are interested in the effects of trade sanctions rather than in those of trade liberalization. They find that the sanctions-induced reduction in the price of the good exported by the country in question will reduce the child wage rate and thus the welfare of low-skill parents. It will have also substitution

\footnotetext{
${ }^{1}$ It is not just a matter of comparing rates of return. Baland and Robinson (2000) show that, even if the return to education is higher than the return to child labour, even altruistic parents may prefer to send a child to work than to invest in his education, because they can appropriate the income produced by a young child, but not that of a grown-up child. Cigno $(2001,2006)$ shows that this may be obviated by the existence of a set of self-enforcing, renegotiation-proof family rules. Pouliot (2006) shows that, given uncertainty, risk-averse parents may prefer the safe return of child labour to the uncertain return of educational investment irrespective of their ability to appropriate the latter.
} 
and income effects on the demand for education. The former will encourage educational investment, but the latter will discourage it. The partial-equilibrium effect of the child wage rate reduction on the demand for education is thus ambiguous (positive if we assume that the substitution-effect dominates the income-effect). The general-equilibrium effect is more complicated, because not only the child wage rate, but also the interest rate may be affected. The authors conclude that trade sanctions are less likely to reduce educational investment (raise child labour), if the interest rate is either formed in a perfect domestic credit market or fixed by the international credit market, than if it is formed in an imperfect domestic market. As sanctions are an obstacle to trade, we can then say that trade liberalization (removing those sanctions) is more likely to reduce child labour if the interest rate is formed in an imperfect domestic market, than if it is either formed in an perfect domestic credit market or internationally determined.

The Jafarey-Lahiri analysis highlights the interest-rate effect of trade. But there are other channels through which trade impinges on parental decisions. The removal of barriers to cross-frontier trade and investment improves the allocation of resources and raises income. Other things being equal, and realistically assuming credit market imperfection, liberalization would thus relax liquidity constraints and reduce child labour. Other things are not equal however. If wage rates fell as a result of liberalization, for example, wage earners could become poorer despite the increase in average income. Assuming that workers are, on average, poorer than capitalists, the liquidity constraint would then become tighter for precisely those families where children are more at risk of becoming premature workers, and child labour would consequently increase. Alternatively, suppose that, following liberalization, the wage rate accruing to skilled workers rises, and that accruing to unskilled ones falls. Assuming that the former is in any case higher than the latter, the liquidity constraint will again tighten for those families where children are more at risk of going to work. On the other hand, however, the skill premium (the skilled to the unskilled wage ratio) and thus the return to education will rise. The effect on aggregate child labour is thus ambiguous. It will be ambiguous also in the opposite case, where the skilled wage rate falls and the unskilled wage rate rises, because the liquidity constraint will then become less stringent for the families where the children are more at risk of becoming workers, but the return to education will fall. If we make the customary assumption that the substitution-effect predominates over the income-effect, however, we may expect trade liberalization to discourage child labour if the skilled to unskilled wage ratio rises, to encourage it if the ratio falls.

Traditional Heckscher-Ohlin theory predicts that, if a country opens itself to trade, it will specialize further in the production of the goods that make more intensive use of its comparatively more abundant untradable factor. If the untradable factors are capital and labour as in the standard North-South model, trade liberalization will then induce the labour-abundant South to specialize further in the production of labour-intensive goods, and the capital-abundant North to specialize further in that of capital-intensive goods. The wage rate 
will consequently rise in the South and fall in the North (Stolper-Samuelson theorem). If the untradable factors are skilled (more educated) and unskilled (less educated) labour as in Adrian Wood's re-interpretation of the North-South model, liberalization will induce the skill-abundant North to specialize further in the production of goods with a high skill content, and the skill-poor South to specialize further in the production of goods with a low skill content (Wood 1994). With trade liberalization, therefore, the skilled wage rate will rise relative to the unskilled wage rate in the North, and fall in the South. ${ }^{2}$ This prediction does not appear to be borne out by the facts however. Empirical research shows that, in the 1980s and 1990s, increased openness was associated with a rise in the skilled to unskilled wage ratio not only in the North, but also in parts of the South, notably in middle-income Latin America (see Freeman and Oostendorp 2001, Feenstra and Hanson 1996, Robbins 1996, Wood 1997) and in some low-income countries (see UNCTAD 1997). Indeed, Leamer $(1996,1998)$ finds that unskilled wage rates did not fall everywhere in the developed world. Finally, Cigno et al. (2002) and Cigno (2003) find that the developing countries where increased openness was associated with a reduction in child labour were those where the share of educated workers in the total adult labour force was comparatively larger.

The limitation of the Hecksher-Ohlin framework is that it only envisages trade in final goods. In recent decades, however, there has been a very sharp increase in the trade of intermediate goods, and in the relocation of the factories producing such goods from developed to developing countries. If the productive activities so relocated were more skill-intensive than those originally carried out in the destination country, this will have caused the demand for skilled labour to shift upwards, and thus put upwards pressure on that country's skilled to unskilled wage ratio. Depending on whether this or the Stolper-SamuelsonWood effect prevailed, the skill premium could have thus risen or fallen. By contrast, if the relocated activities were less skill-intensive than those originally carried out in the destination country, this will have reinforced the StolperSamuelson-Wood effect, and the skill premium will have consequently fallen.

In Section 2 below, we report some broad facts concerning trade, FDI, relative wages, income, education and child labour in developing countries. In Section 3 we graft a family decision model on to a trade model incorporating the theoretical insights of Feenstra and Hanson (1996), and Wood (1997, 2002). In Section 4, we bring the theory to the data. Section 5 concludes.

\section{Stylized facts}

The present section presents the facts that motivated our theoretical and empirical analyses. Figures and tables appear at the end of the paper. Figure 1 plots the child labour rate against the share of school-age children not enrolled at school. The correlation is positive, but the dispersion is fairly high. As pointed

\footnotetext{
${ }^{2}$ The implications for poverty and inequality are discussed in Cline (1997), Zhu and Trefler (2005), and Basu (2006).
} 
out by, among others, Cigno and Rosati $(2002,2005)$, that is because many of the children enrolled at school in developing countries work at the same time, and some children are reported as neither working nor enrolled at school. As argued in Cigno 2012), however, child labour is a good inverse proxy for effective education, because working children dedicate less time to school attendance, homework and rest, and perform less well at school, than non-working children.

Figure 2 plots child labour against per-capita GDP. It also shows the child labour rate predicted by a Generalized Linear Model regression with a binomial distribution and a logit link function. By construction, this model takes into account the nonlinearities due to the fact that the dependent variable is constrained between 0 and 1 . The correlation is negative but small, suggesting the presence of other important co-variates. Since the regression model is non-linear, it is informative to show how the marginal effect of per-capita GDP on the incidence of child labour varies with per-capita GDP. As Table 2 shows, this effect is clearly decreasing in per-capita income. For low income economies, those with per-capita GDP below 1,000 dollars a year according to the World Bank definition, a $1 \%$ increase in per-capita GDP is associated with a $10 \%$ reduction in child labour. For lower-middle income economies, those with percapita GDP between 1000 and 4000 dollars, the marginal effects are less than half those estimated for poorer economies. For upper-middle income economies, those with per-capita GDP above 4000 dollars, the reduction is less than $4 \%$, falling to about $2 \%$ for higher income countries. Therefore, the association between child labour and per-capita GDP loses importance as the latter becomes larger. If we want to explain child labour in countries other than those with less than 1,000 dollars of GDP per capita, we must look for different mechanisms.

The literature reviewed in the last section suggests that trade openness, FDI and skill endowments also affect child labour. If we plot child labour against some measure of trade openness (e.g., import plus exports over GDP), we find that the correlation is negative, but very low, indicating that the effect of trade openness is mediated by, and the sign of this effect possibly depends on other variables. Over the last decade, developing countries have increased their participation in international trade, and their ability to attract foreign direct investment. By 2013, these countries accounted for over a half of the FDI total (WIR, 2014). As Figure 3 shows, Africa in particular saw an increase in the FDI inflow that brought it back to almost its pre-crisis level. If we plot child labour against FDI, however, we again find a negative but very low (especially at low investment levels) correlation between the two.

The literature leads us to expect a relationship also between child labour (or school enrolment) and the skill premium (measured as the educated-touneducated wage ratio), and between the skill premium, some measure of the skill endowment (e.g., the share of the population with completed primary or higher education) and trade openness. As our child labour and wage data come from different sets, we cannot plot one against the other. Looking at the regional averages reported in Table 1 , however, we detect signs of a possibly negative association between child labour and the skill premium. If we plot the skill premium against trade openness or skill endowment we find no clear pattern. 
As shown in Table 6, however, the skill premium is significantly and positively affected by both trade openness and skill endowment, and significantly and negatively affected by their interaction, suggesting that trade reduces the skill premium (and thus encourages child labour) in developing countries with a small share of educated adult workers, but raises the skill premium (and thus encourages educational investment) in developing countries with a relatively large share of educated adult workers. These statistical regularities encourage us to investigate further the role of educational investment before, and FDI after, trade liberalization in the determination of child labour. The next section will help us to formulate testable hypotheses.

\section{$3 \quad$ Theoretical analysis}

Consider a two-period, two-country model of the world economy. ${ }^{3}$ There are two intermediate goods, $x_{1}$ and $x_{2}$, and three final goods, $A, B$ and $C$. $A$ is costlessly assembled from $x_{1}$ and $x_{2}$. The other goods are produced with skilled and unskilled labour. While $x_{1}$ can be produced in either country, $x_{2}$ can be produced only in the North. ${ }^{4}$ In each period $t=1,2$, each country $i=N, S$ (where $N$ stands for North and $S$ for South) is populated by a measure one of families. Each family consists of a mother and her son. In period 1, the mother is a working-age adult, and her son a school-age child. In period 2, the mother is old, and her son a working-age adult. In period 1, mother and son are endowed with one unit of time each. In period 2, the son is endowed with one unit of time. The model bears similarities with Zhu and Trefler (2005). There, however, the objective is to examine the effect of trade and FDI on wage inequality in both the North and the South of the world. Here, by contrast, the ultimate aim is to establish the effect on child labour, and the analysis is focussed on the South.

Let $q_{t i}$ denote the wage rate accruing to skilled labour, and $w_{t i}$ that accruing to unskilled labour, in country $i$ at time $t$. Preferences, technology and relative factor endowments are assumed to be such, that

$$
\frac{q_{t S}}{w_{t S}}>\frac{q_{t N}}{w_{t N}}, t=1,2 .
$$

Put another way, we call North the country where skilled labour is so abundant, in period 1, that no matter how much the other country, called South, invests in its children's education in period 1, it cannot catch up with it by period 2 . Trade barriers are prohibitively high in period 1, but it is common knowledge that they will come down in period 2. There is no migration in either period.

In period 1 , agents correctly anticipate period-2 prices and wages. Given this assumption, the equilibrium can be found in one shot (no backward-induction

\footnotetext{
${ }^{3}$ For technical detail, see Feenstra and Hanson (1996), Wood (2000), and textbook expositions of the Hecksher-Ohlin model.

${ }^{4}$ We can imagine that the technology used to produce $x_{2}$ cannot be imitated by competitors because it is a complex skill-intensive technology that does not generate informational spillovers; see Thoenig and Verdier (2003).
} 
problem). For ease of exposition, however, we first look for the period-1 equilibrium conditional on period-2 prices and wages, and then solve the intertemporal equilibrium problem. As child labour is concentrated mostly in developing countries, we focus on the latter.

\subsection{Period-1 decisions and conditional equilibrium}

In this period, mothers inelastically supply their time endowment to the labour market. Sons spend a fraction $e$ of their time endowment studying, and a fraction $(1-e)$ working. ${ }^{5}$ A child spending a fraction $e$ of his time studying in period 1 has a probability $0 \leq \pi(e) \leq 1$ of becoming skilled in period 2. For simplicity, we assume

$$
\pi(e)=e, 0 \leq e \leq 1 .
$$

As child labour is obviously unskilled (and assuming, for simplicity, that the child wage rate is equal to the unskilled adult wage rate), the opportunity-cost of education is $w_{S 1}$. We do not consider other educational costs.

In the South, a fraction $a_{1}$ of mothers is skilled, and a fraction $1-a_{1}$ unskilled. A family is said to be of type $H$ if the mother is skilled, of type $L$ if she is unskilled. Given $q_{1 S}, w_{1 S}, q_{2 S}$ and $w_{2 S}$, a type- $j$ family $(j=H, L)$ solves the optimization problem

$$
\begin{aligned}
\operatorname{Max}_{S 1} & \left.=E\left[\ln B_{1}+\gamma(\ln k)\right)\right] \\
\text { s.t. } 0 & \leq e \leq 1 \\
R_{j} & =P_{B 1} B_{1},
\end{aligned}
$$

where $U_{S 1}$ is the mother's utility function, $B_{1}$ the quantity consumed and $P_{B 1}$ the price of good $\mathrm{B}$, and

$$
\begin{aligned}
R_{j} & =w_{1 S}+(1-e) w_{1 S} \text { if } j=L \\
R_{j} & =q_{2 S}+(1-e) w_{1 S} \text { if } j=H \\
k & =q_{2 S} \text { with probability } e \\
k & =w_{2 S} \text { with probability } 1-e .
\end{aligned}
$$

Notice that parents do not internalize their children's preferences. The dependence of $U_{S 1}$ on $k$ may reflect either a paternalistic interest in the child's future earning capacity, or the existence of a set of self-enforcing, renegotiation-proof rules conditioning the child's period- 2 support for the parent on the parent's period-1 support for the child (see Cigno 1993, 2006). ${ }^{6}$

\footnotetext{
${ }^{5}$ As noted in the last section, the correlation between labour participation and non-school enrolment is positive but less than perfect. Here, however, $e$ is the time that a child spends studying (including homework), rather than the share of school-age children enrolled for education. As we are talking of poor countries, it seems reasonable to simplify the analysis by assuming that the time left to a child after the minimum necessary amount of rest will be entirely spent studying or working (see Cigno 2012 and references therein).

${ }^{6}$ Given that parents do not save, and thus expect to be supported by their childen in old age, the second interpretation is the most appropriate.
} 
At an interior solution,

$$
\begin{gathered}
B_{j 1}^{*}=\frac{w_{1 S}}{\gamma P_{B 1} \ln \left(\frac{q_{2 S}}{w_{2 S}}\right)}, j=H, S, \\
e_{H}^{*}=1+\frac{q_{1 S}}{w_{1 S}}-\frac{1}{\gamma \ln \left(\frac{q_{2 S}}{w_{2 S}}\right)}
\end{gathered}
$$

and

$$
e_{L}^{*}=2-\frac{1}{\gamma \ln \left(\frac{q_{2 S}}{w_{2 S}}\right)} .
$$

Therefore,

$$
B_{1}^{*} \equiv a_{1} B_{H 1}^{*}+\left(1-a_{1}\right) B_{L 1}^{*}=\frac{w_{1 S}}{\gamma P_{B 1} \ln \left(\frac{q_{2 S}}{w_{2 S}}\right)}
$$

and

$$
e_{L}^{*} \equiv a_{1} e_{H}^{*}+\left(1-a_{1}\right) e_{L}^{*}=2+a_{1}\left(\frac{q_{1 S}}{w_{1 S}}-1\right)-\frac{1}{\gamma \ln \left(\frac{q_{2 S}}{w_{2 S}}\right)} .
$$

This tells us that the South's aggregate period- 1 demand for good $B$ is decreasing in the expected skill premium $\frac{q_{2 S}}{w_{2 S}}$. By contrast, its aggregate period-1 educational investment and, consequently, period-2 share of skilled workers in the adult workforce, denoted by $a_{2}$, is increasing in $a_{1}, \frac{q_{1 S}}{w_{1 S}}$ and $\frac{q_{2 S}}{w_{2 S}}$.

We now look for a period-1 equilibrium conditional on the expected skill premium. In each period $t, B$ is produced by a constant-returns-to-scale technology,

$$
B_{t}=L_{t B}^{\beta} H_{t B}^{1-\beta}, 0<\beta<1,
$$

where $H_{t B}$ denotes the quantity of skilled labour, and $L_{t B}$ that of unskilled labour, employed in this activity. The cost-minimizing inputs of skilled and unskilled labour per unit of output are, respectively,

$$
h_{t B}^{*}=\left(\frac{\beta}{1-\beta} \frac{q_{1 S}}{w_{1 S}}\right)^{-\beta}
$$

and

$$
l_{t B}^{*}=\left(\frac{\beta}{1-\beta} \frac{q_{t S}}{w_{t S}}\right)^{1-\beta} .
$$

For the zero-profit condition,

$$
P_{B 1}=l_{B}^{*} w_{1 s}+h_{B}^{*} q_{1 s} .
$$

For the labour markets to clear, it must be true that

$$
H_{S}=a_{1}=h_{B}^{*} \frac{w_{1 s}}{P_{B} \gamma\left(\ln \frac{q_{2 S}}{w_{2 S}}\right)}
$$

\footnotetext{
${ }^{7}$ Good $B$ may be thought to include not only the product of subsistence agriculture and informal activities, but also industrial products of less than export quality (Wood, 2000).
} 
and

$$
L_{S}=1-a_{1}=l_{B}^{*} \frac{w_{1 s}}{P_{B} \gamma\left(\ln \frac{q_{2 S}}{w_{2 S}}\right)} .
$$

Given $a_{1}$ and the expected value of $\frac{q_{2 S}}{w_{2 S}}$, equations $(3)-(7)$ simultaneously determine $P_{B 1}, w_{1 S}$ and $q_{1 S}{ }^{8}$

\subsection{Period-2 decisions and intertemporal equilibrium}

In this period, the South can import $x_{2}$ from the North. This gives the former the opportunity of domestically producing the intermediate good $x_{1}$ by the constant-returns-to-scale technology

$$
x_{1}=L_{x_{1}}^{\varepsilon} H_{x_{1}}^{1-\varepsilon}, 0<\varepsilon<1,
$$

and then costlessly assemble the final good $A$ from $x_{1}$ and $x_{2}$ by the constantreturns-to-scale technology

$$
A=x_{1}^{\alpha} x_{2}^{1-\alpha}, 0<\alpha<1 .
$$

The North may now choose to import $x_{1}$ from the South instead of producing it locally.

The period-2, the cost-minimizing quantities of skilled and unskilled labour employed in country $S$ to produce a unit of $x_{1}$ are, respectively,

$$
h_{x_{1}}^{*}=\left(\frac{\varepsilon}{1-\varepsilon} \frac{q_{2 S}}{w_{2 S}}\right)^{-\varepsilon}
$$

and

$$
l_{x_{1}}^{*}=\left(\frac{\varepsilon}{1-\varepsilon} \frac{q_{2 i}}{w_{2 S}}\right)^{1-\varepsilon} .
$$

The period-2 unit cost of producing $x_{1}$ in country $S$ is

$$
c_{1 S}=w_{2 i} l_{x_{1}}^{*}+q_{2 i} h_{x_{1}}^{*} .
$$

Denoting by $c_{1 N}$ the period- 2 unit cost of producing $x_{1}$ in country $N$, and realistically assuming

$$
c_{1 N}>c_{1 S}
$$

$x_{1}$ will be produced only in country $S$. We may interpret this as saying that the North's $x_{1}$ producers relocate their factories to the South. ${ }^{9}$ As $x_{1}$ will be

\footnotetext{
${ }^{8}$ Similar expressions may be derived also for the North. As our attention is focussed on the South, however, we limit ourselves to assuming (1).

${ }^{9}$ In Tang and Wood (2000), this is induced by a fall in co-operation cost that makes it advantageous to transfer entrepreneurs, designers, engineers and other professionals from the North to the South. In Feenstra and Hanson (1996), offshoring is made profitable by the fall in in the cost of production of the South relative to that of the North. This fall is explained by capital flows lowering the interest rate in the South relative to the North. Both these arguments could be applied also to our model. For simplicity, however, we have directly assumed that trade liberalization makes it possible and advantageous for the North to import $x_{1}$ from the South.
} 
produced only in the South, and $x_{2}$ can be produced only in the North, we can then write, dispensing with country subscripts,

$$
x_{1}^{*}=\left(\frac{\alpha}{1-\alpha} \frac{c_{2}}{c_{1}}\right)^{1-\alpha}
$$

and

$$
x_{2}^{*}=\left(\frac{\alpha}{1-\alpha} \frac{c_{2}}{c_{1}}\right)^{-\alpha},
$$

where $c_{2}$ denotes the period-2 unit cost of $x_{2} \cdot{ }^{10}$ The period-2 unit cost of $A$ will be

$$
c_{A}=x_{1}^{*} c_{1}+x_{2}^{*} c_{2} .
$$

In the South, the average family solves

$$
\begin{aligned}
\operatorname{Max}_{S 2} & =\ln B_{S 2}+\gamma \ln A_{S 2} \\
\text { s.t. } Y_{S 2} & =P_{B 2} B_{2}+P_{A 2} A_{S 2},
\end{aligned}
$$

where $U_{S 2}$ is the son's utility, $A_{S 2}$ and $B_{S 2}$ are the average period-2 consumption levels of the two final goods, and

$$
Y_{S}=a_{2} q_{2 S}+\left(1-a_{2}\right) w_{2 S}
$$

is the average period- 2 income. Using the first-order conditions, we can derive the South's period-2 demands for the two final goods,

$$
\begin{aligned}
A_{S}^{D} & =\frac{\gamma}{1+\gamma} \frac{Y_{s}}{P_{A}} \\
B_{S}^{D} & =\frac{1}{1+\gamma} \frac{Y_{s}}{P_{B}},
\end{aligned}
$$

and for the two intermediate goods,

$$
\begin{aligned}
& x_{1}^{S}=x_{1}^{*} A_{S}^{D} \\
& x_{2}^{S}=x_{2}^{*} A_{S}^{D} .
\end{aligned}
$$

Therefore,

$$
\frac{A_{S}^{D}}{B_{S}^{D}}=\gamma \frac{P_{B 2}}{P_{A 2}} .
$$

The North's family optimization problem is

$$
\begin{aligned}
\operatorname{Max}_{N 2} & =\ln C_{N 2}+\gamma \ln A_{N 2} \\
\text { s.t. } Y_{N} & =P_{C} Q_{C}+P_{A} Q_{A},
\end{aligned}
$$

\footnotetext{
${ }^{10}$ As we have not modelled the production of $x_{2}$, we do not have a cost function for it. We will thus treat $c_{2}$ as a parameter.
} 
where $A_{N 2}$ and $C_{N 2}$ denote the average quantities consumed of the two goods, $U_{N 2}$ is the son's utility, and, $Y_{N}$ the average income. Therefore, the North's demands for $x_{1}, x_{2}$ and $A$ are, respectively,

$$
\begin{aligned}
& x_{1}^{D N}=x_{1}^{*} Q_{A}^{D N} \\
& x_{2}^{D N}=x_{2}^{*} Q_{A}^{D N}
\end{aligned}
$$

and

$$
A_{N}^{D}=\frac{\gamma}{1+\gamma} \frac{Y_{N}}{P_{A}} .
$$

Using the balance-of-trade equilibrium condition

$$
x_{2}^{*} Q_{A}^{D S}=x_{1}^{*} Q_{A}^{D N},
$$

and substituting from (14) and (18), we find

$$
\frac{x_{2}^{*} Q_{A}^{D S}}{x_{1}^{*} Q_{A}^{D N}}=\frac{x_{2}^{*} Y_{S}}{x_{1}^{*} Y_{N}}=1 .
$$

For the zero-profit condition, prices will be equal to unit costs. Therefore,

$$
P_{A 2}=x_{1}^{*} l_{x_{1}}^{*} w_{2 S}+x_{1}^{*} h_{x_{1}}^{*} q_{2 S}+x_{2}^{*} c_{2}
$$

and

$$
P_{B 2}=l_{B}^{*} w_{2 S}+h_{B}^{*} q_{2 S} .
$$

Equilibrium in the South's labour markets further requires that

$$
a_{2}=h_{B}^{*} B_{B}^{D}+x_{1}^{*} h_{x_{1}}^{*} Q_{A}^{D S}
$$

and

$$
1-a_{2}=l_{B}^{*} Q_{B}^{D}+x_{1}^{*} l_{x_{1}}^{*} Q_{A}^{D S} .
$$

Assumption. No factor-intensity reversal (NFIR): $\forall \frac{q_{2 S}}{w_{2 S}}$, either

$$
\text { or } \quad \begin{array}{ll}
\frac{x_{1}^{*} h_{x_{1}}^{*}}{x_{1}^{*} l_{x_{1}}^{*}}>\frac{h_{B}^{*}}{l_{B}^{*}} \\
\frac{x_{1}^{*} h_{x_{1}}^{*}}{x_{1}^{*} l_{x_{1}}^{*}}<\frac{h_{B}^{*}}{l_{B}^{*}}
\end{array}
$$

Recalling that the ratio of skilled to unskilled workers employed in the production of good $A$ depends only on the ratio of skilled to unskilled workers employed in the production of $x_{1}$, and that the ratio of skilled to unskilled workers employed in the production of $B$ is calculated as a residual, the South's period-2 equilibrium wage ratio is then determined by the need to induce the producers of $B$ to employ that residual mix of skilled and unskilled workers. If 
(22) holds, these producers will then employ a more skill-intensive labour mix than they did in period 1, and the South's skill premium will consequently rise,

$$
\frac{q_{2 s}}{w_{2 s}}>\frac{q_{1 s}}{w_{1 s}} .
$$

Conversely, if (23) holds, they will employ a less skill-intensive labour mix than in period 1, and the South's skill premium will fall,

$$
\frac{q_{2 S}}{w_{2 S}}<\frac{q_{1 s}}{w_{1 S}} .
$$

In each case, the size of the wage change will depend on the change in the stock of skilled adults between periods 1 and 2, and thus on the amount that southern parents invested in their children's education in period 1. Having assumed that parents correctly anticipate future wages, the amount parents invest in their children's education will be larger if (22) holds, than if (23) does.

Proposition. There exists a two-way relationship between $\frac{P_{A}}{P_{B}}$ and $\frac{q_{2 S}}{w_{2 S}}$, such that

$$
\frac{P_{A}}{P_{B}}=\frac{1}{\alpha} \varphi\left(\frac{q_{2 S}}{w_{2 S}}\right), \varphi^{\prime}>0 \text { for }(22), \varphi^{\prime}<0 \text { ifor }(23) . .
$$

Proof. Note that $x_{2}^{*} c_{2}=(1-\alpha) P_{A}$, Substituting in (19) we then obtain

$$
\alpha P_{A}=x_{1}^{*} l_{x_{1}}^{*} w_{s}+x_{1}^{*} h_{x_{1}}^{*} q_{s},
$$

which, combined with (20), implies

$$
\frac{P_{A 2}}{P_{B 2}}=\frac{1}{\alpha} \frac{x_{1}^{*} l_{x_{1}}^{*}+\frac{q_{2 s}}{w_{2 s}} x_{1}^{*} h_{x_{1}}^{*}\left(\frac{q_{2 s}}{w_{2 s}}\right)+\frac{q_{2 s}}{w_{2 s}} h_{B}^{*}\left(\frac{q_{2 s}}{w_{2 s}}\right)}{w_{1}} .
$$

Given NFIR, (24) then follows.

Given the South's relative demand and relative supply functions are, respectively,

$$
\frac{A_{S}^{D}}{B_{S}^{D}}=\gamma \frac{P_{B 2}}{P_{A 2}}
$$

and

$$
\frac{A^{S}}{B^{S}}=\Psi\left(\frac{P_{A 2}}{P_{B 2}}, \frac{a_{2}}{1-a_{2}}, \alpha\right),
$$

with $\Psi_{\frac{P_{A}}{P B}}^{\prime}>0, \Psi_{\frac{a_{2}}{1-a_{2}}}^{\prime}>0$ for (22), $\Psi_{\frac{a_{2}}{1-a_{2}}}^{\prime}<0$ for (23), and $\Psi_{\alpha}^{\prime}>0$, the equilibrium price ratio will satisfy

$$
\gamma \frac{P_{B}}{P_{A}}=\Psi\left(\frac{P_{A}}{P B}, \frac{a_{2}}{1-a_{2}}, \alpha\right) .
$$


Let $p \equiv \frac{P_{A}}{P B}$ denote the equilibrium price ratio, and $r \equiv \frac{a_{2}}{1-a_{2}}$ the equilibrium ratio of skilled to unskilled workers ratio, in period 2. Given that, $\frac{\partial p}{\partial \alpha}=-\frac{\Psi_{\alpha}}{\gamma+\Psi_{p}}$ and $\frac{\partial p}{\partial \gamma}=\frac{1}{\left(\gamma+\Psi_{p}\right) p}, p$ is decreasing in the technological parameter $\alpha$ (the more important is $x_{1}$ in the production of $A$, the lower is $p$ ), and increasing in the preference parameter $\gamma$ (the better consumers like $A$, the higher is $p$ ). Given

that $\frac{\partial p}{\partial r}=-\frac{\Psi_{r}}{\gamma+\Psi_{p}}, p$ will be decreasing or increasing in $r$ according to whether (22) or (23) is true.

We are now equipped to examine the effects of period-2 trade liberalization on the South's period-1 education decisions. Let $\omega_{1} \equiv \frac{q_{1 S}}{w_{1 S}}$ and $\omega_{2} \equiv \frac{q_{2 S}}{w_{2 S}}$. We know that aggregate educational investment is increasing, and the child labour rate consequently decreasing, in $a_{1}$ and $\omega_{2}$. We also know that $\omega_{2}$ will be higher than $\omega_{1}$ if (22) holds, lower than it if (23) does. Given $a_{1}$, trade liberalization will then cause child labour to fall if $x_{1}$ is more skill-intensive than $B$, to rise if $x_{1}$ is less skill-intensive than $B$. The fall (rise) will be larger (smaller) if $a_{1}$ is high, than if $a_{1}$ is low. This prediction contrasts with that implied by Adrian Wood's version of the Hecksher-Ohlin model, where trade liberalization necessarily reduces the South's skill premium. If we introduced family choice in that model, we would in fact find that, contrary to the evidence, trade liberalization necessarily discourages education and raises child labour in developing countries.

The reason why trade liberalization does not necessarily depress the skill premium and discourage education in the South according to our model is that liberalization encourages offshoring. Depending on whether the activities relocated from the North to the South are more or less skill-intensive than those already carried out in the latter, liberalization may in fact put either upwards or downwards pressure on the South's skilled to unskilled wage ratio. In the first case, offshoring will reinforce the Stolper-Samuelson-Wood effect, the South's skill premium will consequently fall, and child labour will rise. In the second, by contrast, offshoring will tend to offset, and possibly more than offset, the Stolper-Samuelson-Wood effect. The larger is the South's initial skill endowment, the more skill-intensive will the production activities relocated there be. The more likely it then is that trade liberalization will raise the South's skill premium, and reduce its child labour rate.

\section{Empirical analysis}

In this section, we estimate the effects of a country's skill endowment and exposure to foreign trade on that country's skill premium and child labour rate. We use two separate datasets. The first is obtained by matching and merging data from different sources, mainly UNICEF, UNESCO, World Bank, and ILO and considering different proxies for the variables of interest. We also insert variables coming from the Barro and Lee dataset, accessed on line on November 2014. The second dataset exploits the information on wages and employment provided by UNIDO, and is used exclusively to calculate the skill premium. To 
proxy the skill endowment, we use the average number of years of education or, alternatively, the stock of persons with completed primary education. The precise definition of the variables, together with the specific source for each variable are reported in the Appendix.

Given that, according to our theoretical predictions, the child labour effects come at least in part through induced changes in the domestic skill premium, the two variables should be estimated simultaneously. Given, however, that the data come from different sources, we had no choice but to separately estimate a child labour equation and a skill premium equation. Given that it takes time for trade liberalization to affect FDI and domestic wage rates, and for these induced changes to affect parental decisions, we lag trade openness 5 years. As the child labour data set is assembled from different surveys concerning different years, we could only carry out cross-section estimates. The number of observations in the dataset used to estimate the child labour equation is limited. Indeed, there are data on child labour for only 109 countries. For most of them, we were able to find data on skill endowments (either average years of education as suggested in Barro and Lee, or completed primary education). When we introduce other explanatory variables (e.g., FDI), the sample gets smaller for lack of data The exact number of observations on which the estimates are run is indicated in each table and for each equation.

Table 3 shows an estimate of the child labour equation obtained by a Generalized Linear Model regression with a binomial distribution and a logit link function ${ }^{11}$. Child labour is strongly affected by skill endowment (measured as the share of adults with at least primary education, L5pri_stock) and trade openness (measured as the trade ratio, L5-open), both lagged five years. The coefficients are significantly different from zero. Per-capita GDP (GDP_pc) also has a negative effect, but the coefficient is smaller and less significant than it would be without the lagged variables, suggesting that income is partly determined by trade ${ }^{12}$. Table 4 shows what happens if we add FDI to the list of explanatory variables. The coefficient of this variable is negative and significantly different from zero. The other coefficients are smaller than in Table 3, as expected. We are aware that FDI is potentially endogenous, but we do not have enough degrees of freedom to instrument it. The fact that the numerical values of the coefficients are very stable, however, is a good rule-of-thumb indicator that the estimates are reliable.

We tried to separate the countries that reduced trade openness from those that increased it in the five years preceding the labour survey (on average, between 2005 and 2010-11). As shown in Table 5, the average degree of openness (0.89) at the end of the quinquennium in the countries that reduced trade openness is very similar to the average degree of openness (0.865) at the start of the quinquennium in the countries that increased trade openness. The regressions

\footnotetext{
${ }^{11}$ We also tried different estimation methods, and the results were very stable. The results of these other regressions are available on request.

${ }^{12}$ We also tried to estimate child labour on GDP, as in Edmonds 2008, or child labour on trade openess and skill endowments alone. Contrary to other papers, in our case the numerical coefficents are very stable and the significance level of the different regressors does not change.
} 
run on the two subsamples confirm the negative child labour effects of income and lagged skill endowment, but the number of observations is too small to draw firm conclusions, or to consider other explanatory variables.

Table 6 shows the skill premium (measured by the skilled-to-unskilled wage ratio) effects of all the variables, other than FDI, ${ }^{13}$ that were used to explain child labour. Consistently with the proposition that income affects child labour decisions via the liquidity constraint, not via relative wages, per-capita GDP has no significant effect on the skill premium. Consistently with the results shown in Table 2, the negative effect of income on child labour shown in Table 4 may thus be thought to reflect the behaviour of the poorer part of the population (for whom the return to education is irrelevant because the credit ration is tight). The skill premium is positively and significantly affected by the skill endowment and by the degree of trade openness, both lagged five years. Their interaction, however, has a negative and significant coefficient. If the country's skill endowment is small, trade then lowers the skill premium (as predicted by Stolper-Samuelson-Wood). If the endowment is sufficiently large, however, trade will raise the skill premium. Our empirical finding is thus consistent with our theoretical prediction that trade liberalization will raise a developing country's skill premium, and reduce its child labour rate, if its stock of skilled workers is large enough to attract sufficiently skill-intensive FDI.

\section{Conclusion}

We have argued theoretically that the lowering of barriers to trade and foreign direct investment may cause a developing country's skill premium to rise, and child labour to fall, if the production activities relocated to that country are more skill-intensive than those already carried out there. Otherwise, liberalization will cause the skill premium to fall, and child labour to rise. This prediction is consistent with the observation that child labour has risen in some developing countries and fallen in other, but it conflicts with an implication of Adrian Wood's version of the Hecksher-Ohlin model, according to which trade liberalization reduces the skill premium in (by definition skill-poor) developing countries, and raises it in (by definition skill-rich) developed countries. If we introduced family choice in that model, we would in fact find that liberalization reduces the incentive to send children to school in developing countries, and will thus raise child labour. The reason why this does not necessarily happen in our model is that liberalization permits and encourages offshoring. If the activities relocated from a developed to a developing country are more skill-intensive than those originally carried out in the latter, that will in fact put upwards pressure on that country's skilled to unskilled wage ratio, and thus tend to offset (possibly, more than offset) the Stolper-Samuelson-Wood effect associated with international specialization. The larger is a developing country's skill endowment at the time when the barriers are lowered, the more skill-intensive

\footnotetext{
${ }^{13}$ We could not consider FDI because we did not have FDI data in this dataset. As it is well known, it is difficult to find reliable bilateral FDI data for developing countries.
} 
will the production activities relocated there be, and the more likely it then is that child labour will fall. The data do not reject this theoretical prediction, and thus help to explain why trade liberalization reduced the skill premium and raised child labour in some developing countries, but not in other. If we buy the Baland-Robinson and Ranjan arguments that child labour is not only undesirable on humanitarian grounds, but also inefficient, lowering barriers to trade and inwards FDI is beneficial if the country starts out on the right foot i.e., if it has already accumulated a stock of educated workers large enough to attract production activities that will raise the skill premium. 


\section{References}

Anderson, E., P. Tang and A. Wood (2006), "Globalization, cooperation costs and wage inequalities" , Oxford Economic Papers 58, 569-95

Baland, J. M. and J. A. Robinson (2000), "Is child labor inefficient?", Journal of Political Economy 108, pp. 663-679

Barro, R. J. and J. W. Lee (2013), "A new data set of educational attainment in the world, 1950-2010", Journal of Development Economics 104, pp. 184-198

Basu, K. (2006), "Globalization, poverty, and inequality: What is the relationship? What can be done?", World Development, 34(8), pp. 1361-1373

- and P. H. Van (1998), "The economics of child labour", American Economic Review 88, pp. 412-427

Chinn, M. D. and H. Ito (2006), "What matters for financial development? Capital controls, institutions, and interactions", Journal of Development Economics 81(1), pp. 163-192

Cigno, A. (1993),"Intergenerational transfers without altruism", European Journal of Political Economy 9, pp. 505-518

- (2003), "Globalization can help reduce child labour", CESifo Economic Studies 49, pp. 515-526

- (2006), "A constitutional theory of the family", Journal of Population Economics 19, pp. 259-283

- (2012), "How to deal with covert child labor, and give children an effective education, in a poor developing country", World Bank Economic Review 26, pp. 61-67

-, L. Guarcello and F. C. Rosati (2002), "Does globalization increase child labour?", World Development 30, pp. 1579-89

and F. C. Rosati (2002), "Child labour, education and nutrition in rural India", Pacific Economic Review 7, pp. 65-83 and F. C. Rosati (2005), The Economics of Child Labour, New York and Oxford: Oxford University Press

Cline, W. (1997), Trade and Income Distribution, Washington DC: Institute for International Economics

Dehejia, R. H. and R. Gatti (2005), "Child labour: the role of income variability and access to credit in a cross section of countries", Economic Development and Cultural Change 53 (4), pp. 913-932

Edmonds, E. V. (2005), "Does child labour decline with improving social status?", Journal of Human Resources 40 (1); 77-99.

- and N. Pavcnik (2006), "International trade and child labour: cross country evidence", Journal of International Economics 68, pp. 115-140

Feenstra, R. and G. Hanson (1996), "Foreign investment outsourcing and relative wages" in R. Feenstra,G. Grossman, and D. Irwin (eds.), Political Economy of Trade Policy. Essays in Honour of Jagdish Bhagwati, Cambridge: MIT Press

Freeman, R. B. and R. H. Oostendorp (2001), "The occupational wages around the World Data File", International Labour Review 140 (4), pp. 379401 
Jafarey, S. and S. Lahiri (2002), "Will trade sanctions reduce child labour? The role of credit markets", Journal of Development Economics 68 (1), pp.13756

Leamer, E. (1996), "In Search of Stolper-Samuelson Effects on U.S. Wages", NBER Working Papers 5427

(1998), "In search for Stolper-Samuelson linkages between international trade and lower wages" in S.Collins (ed.) Imports, Exports, and the American Worker, Washington DC: Brookings Institution Press

Pouliot, W. (2006), "Introducing uncertainty in Baland and Robinson's model of child labour", Journal of Development Economics 79, pp. 264-272

Ranjan, P. (2001), "Credit constraints and the phenomenon of child labour", Journal of Development Economics 64, pp. 81-102

Robbins, D. (1996), "Evidence on trade and wages in developing world", Technical Paper 119, OECD Development Centre, Paris

Tang, P., and A. Wood (2000) "Globalization, Cooperation Costs and Wage Inequalities". Unpublished paper. Netherlands Planning Bureau and Institute of Development Studies, University of Sussex, Brighton (www.ids.ac.uk/ids/global/ttint.html).

Thoenig, M. and T. Verdier (2003), "A theory of defensive skill-biased innovation and globalization", American Economic Review 93(3), pp. 709-728

UNCTAD (1997), Trade and Development Report, Geneva: UNCTAD

UNCTAD (2014), World Investment Report, Investing in the SDGs: An Action Plan, Geneva, UNCTAD

Wood, A. (1994), North-South trade, Employment and Inequality: Changing Fortunes in Skill-Driven World. Oxford, Claredon Press

(1997), " Openness and wage inequality in developing countries: the Latin America challenge to East Asia conventional wisdom", World Bank Economic Review 11(1), pp. 33-57

(2002), "Globalization and wage inequalities: a synthesis of three theories", Weltwirtschaftliches Archiv 138 (1), pp. 54-82

Zhu, S. C. and D. Trefler (2005), "Trade and inequality in developing countries: a general equilibrium analysis", Journal of International Economics 65, pp. $21-48$

\section{Appendix: Definitions and sources}

\subsection{Variables}

Child labour is defined as the share of children aged 5-14 involved in child labour at the moment of the survey. A child is considered to be involved in child labour under the following conditions: (a) for children aged 5-11 if, during the reference week, if they did at least one hour of economic activity or spent at least 28 hours on household chores, (b) for children aged 12-14 if they did at least 14 hours of economic activity or spent at least 28 hours on household chores.

Skill endowment is the share of skilled adult workers in the country total adult workforce. We use several different proxies for this stock variable. 
edu_years is the population's average number of completed years of education. This indicator widely used as measure of a country's stock of human capital. Since 2010, it is also used as one of two indicators entering the Human Development Index. pri_stock and sec_stock are, respectively, the shares of the labor force with at least primary and at least secondary education. eduprisur is the survival rate to the last grade of primary education. edu_sch is total enrollment in secondary education, regardless of age, as a percentage of the secondary-school age population (due to early or late school entrance and grade repetition, this indicator can exceed $100 \%$. L5pri stock and L5sec stock are pri_stock and sec_stock lagged 5 years. L5sec_stock performed best. Primary (secondary) enrollment is the share of children in the primary (secondary) school age range actually enrolled for primary (secondary) education.

Skill premium is the skilled/unskilled wage ratio, computed dividing the wages in medium-high tech industries by wages in low tech industries.

open is trade openness as measured by the trade ratio (imports plus exports over GDP.

L5_open is the trade ratio lagged 5 years.

kaopen is the Chinn-Ito index of capital account openness.

FDI is net inward foreign direct investment over GDP

GDP_pc is per capita GDP

\subsection{Sources}

We use two different dataset. The first is built matching and merging data from different sources, mainly UNICEF, UNESCO, World Bank, ILO and UNIDO. We also inserted variables coming from the Ito and Chinn-Barro and Lee datasets, accessed on line on November 2014. The second (used only for the wage gap equation) is based on data from the Industrial Statistics Database of the United Nations Industrial Development Organization (UNIDO), which provides annual information on the manufacturing sector for a long period covering the years from 1963 to 2011. Data available from this database includes, among other, information on: total wages, employment, capital, value added and production disaggregated at the 2-digit level of the International Standard Industrial Classification (ISIC) revision 3. We have calculated a measure of wage inequality adopting the following approach

Child labour. The data come mainly from the UNICEF-supported Multiple Indicator Cluster Surveys (MICS) and ILO-supported Statistical Information and Monitoring Programme on Child Labour (SIMPOC) surveys. These data were collected starting in the year 2000 in more than 50 surveys using a standard questionnaire, and a standard definition of child labour to allow comparison. The surveys cover children aged 5 to 14. engaged in "economic activities" (paid or unpaid work for someone who is not a member of the household, or work on the family farm or business) or household chores such as cooking, cleaning and caring for younger children. Some sources report data for children aged 5 to 17 (in which case, the numbers are substantially higher). See 
http://data.unicef.org/child-protection/child-labour, updated November 2014, and http://www.ucw-project.org/pages/interactive-map.aspx.

http://www.ilo.org/ipec/ChildlabourstatisticsSIMPOC/Questionnairessurveysandreports/langen/index.htm contains for time series for a limited number of countries. In some equations we used time series from the ILOSTAT dataset. This allowed us to build an unbalanced panel, but the number of observations left after matching the child labour data with the education data is very small. The regression results, not shown here, are available on request.

GDP: United Nations.

open: United Nations.

kaopen: Chinn and Ito (2008).

Skill endowment: for edu years, Barro and Lee and Wittgenstein Centre for Demography and Global Human Capital (2014). Wittgenstein Centre Data Explorer Version 1.1; for edu_sch: World Bank; for the other indicators, http://data.uis.unesco.org/, accessed on line September 2014 and December 2014 .

Skill premium: UNIDO.

FDI; World Bank.

\section{$7 \quad$ Figures and tables}

Table1. Child labour,school enrolment, skill premium and skill endowment

\begin{tabular}{|c|c|c|c|c|}
\hline & Child labour & $\begin{array}{l}\text { Primary } \\
\text { enrolment }\end{array}$ & $\begin{array}{c}\text { Secondary } \\
\text { enrolment }\end{array}$ & Skill premium \\
\hline Sub-Saharan Africa & 25 & 77 & n. a. & 1.22 \\
\hline West and Central Africa & 25 & 87 & 30 & n. a. \\
\hline Eastern and Southern Africa & 25 & 68 & n. a. & n. a. \\
\hline Middle East and North Africa & 9 & 90 & 66 & 1.49 \\
\hline South Asia (excluding India) & 12 & 93 & 50 & 1.26 \\
\hline East Asia and Pacific (excluding China) & 8 & 97 & 72 & 1.33 \\
\hline Latin America and Caribbean & 11 & 95 & 76 & 1.30 \\
\hline \multicolumn{5}{|c|}{ NOTE: The data for skill premium identify slightly different regions: } \\
\hline \multicolumn{5}{|c|}{ Middle East includes Arab states only. South and West Asia excludes India. } \\
\hline Child labour is defined as Percentage of ch & Idren 5-14 year & & & \\
\hline
\end{tabular}


Table 2. Marginal child labour effects of per-capita GDP

$\begin{array}{lllllll}\text { per-capita GDP }(\$) & \text { dy/dx } & \text { Std. Err } & \mathrm{z} & \mathrm{P}>\mathrm{z} & {[95 \% \text { Conf. }} & \text { Interval }] \\ 100 & -0.123 & 0.018 & -6.92 & 0 & 0.158 & -0.088 \\ 200 & -0.111 & 0.017 & -6.43 & 0 & -0.145 & -0.007 \\ 500 & -0.090 & 0.013 & -6.71 & 0 & -0.116 & -0.064 \\ 1000 & -0.073 & 0.010 & -7.60 & 0 & -0.092 & -9.32 \\ 2000 & -0.057 & 0.006 & -9.32 & 0 & -0.069 & -0.045 \\ 3000 & -0.049 & 0.004 & -10.88 & 0 & -0.057 & 0.040 \\ 5000 & -0.039 & 0.003 & -13.53 & 0 & -0.033 & -0.034 \\ 10000 & -0.029 & 0.002 & -16.50 & 0 & -0.040 & -0.026 \\ 20000 & -0.021 & 0.002- & -14.05 & 0 & -0.024 & -0.018\end{array}$

Table 3. Child labour equation

$\begin{array}{lllllll} & \text { coefficient } & \text { robust SE } & \mathrm{z} & \mathrm{P} z & 95 \% & \mathrm{CI} \\ \text { GDP_pc } & -0.311 & 0.0677 & -4.60 & 0.000 & -0.444 & -0.178 \\ \text { L5pri_stock } & -1.273 & 0.401 & -3.18 & 0.001 & -2.057 & -0.4876 \\ \text { L5-open } & -0.548 & 0.239 & -2.29 & 0.022 & -1-016 & -0.0791 \\ \text { cons } & 1.852 & 0.378 & 4.89 & 0.000 & 1.111 & 2.594 \\ & & & & & & \\ \mathrm{n}=89 & & & & & & \end{array}$

Table 4. Child labour and FDI

$\begin{array}{lllllll} & \text { coefficient } & \text { robust SE } & \text { z } & \text { P z } & 95 \% & \text { CI } \\ \text { GDP_pc } & -0.2799 & 0.1008 & -2.78 & 0.005 & -0.477 & -0.0823 \\ \text { L5pri_stock } & -1.153 & 0.516 & -2.24 & 0.025 & -2.165 & -0.1419 \\ \text { L5-open } & -0.7682 & 0.3699 & -2.08 & 0.038 & -1.493 & -0.0431 \\ \text { FDI } & -0.0193 & 0.008 & -2.38 & 0.017 & -0.0352 & -0.00349 \\ \text { cons } & 1.1827 & 0.529 & 3.45 & 0.001 & 0.7896 & 2.8645 \\ \text { n=54 } & & & & & & \end{array}$

Table 5 .Average change in trade openness over 5 -year period

$\begin{array}{lll} & \text { open } & \text { L5-open } \\ \text { countries that reduced trade openness } & 0.890 & 0.718 \\ \text { countries that increased trade openness } & 0.769 & 0.865 \\ \text { total } & 0.843 & 0.775\end{array}$


Table 6. Skill premium equation

$\begin{array}{lc}\text { lnGDP_pc } & -0.02 \\ & (0.015) \\ \text { L5primarystock } & 0.724^{* *} \\ & (0.220) \\ \text { L5open } & 0.190^{*} \\ & (0.253) \\ \text { interaction L5primarystockL5open } & -0.692^{* *} \\ & (0.253) \\ \text { const } & 1.365^{* *} \\ & (0.177)\end{array}$

Note: ${ }^{*} \mathrm{p}<0.05,{ }^{* *} \mathrm{p}<0.01,{ }^{* * *} \mathrm{p}<0.001$

Figure 1. Correlation between child labour and non-school enrolment

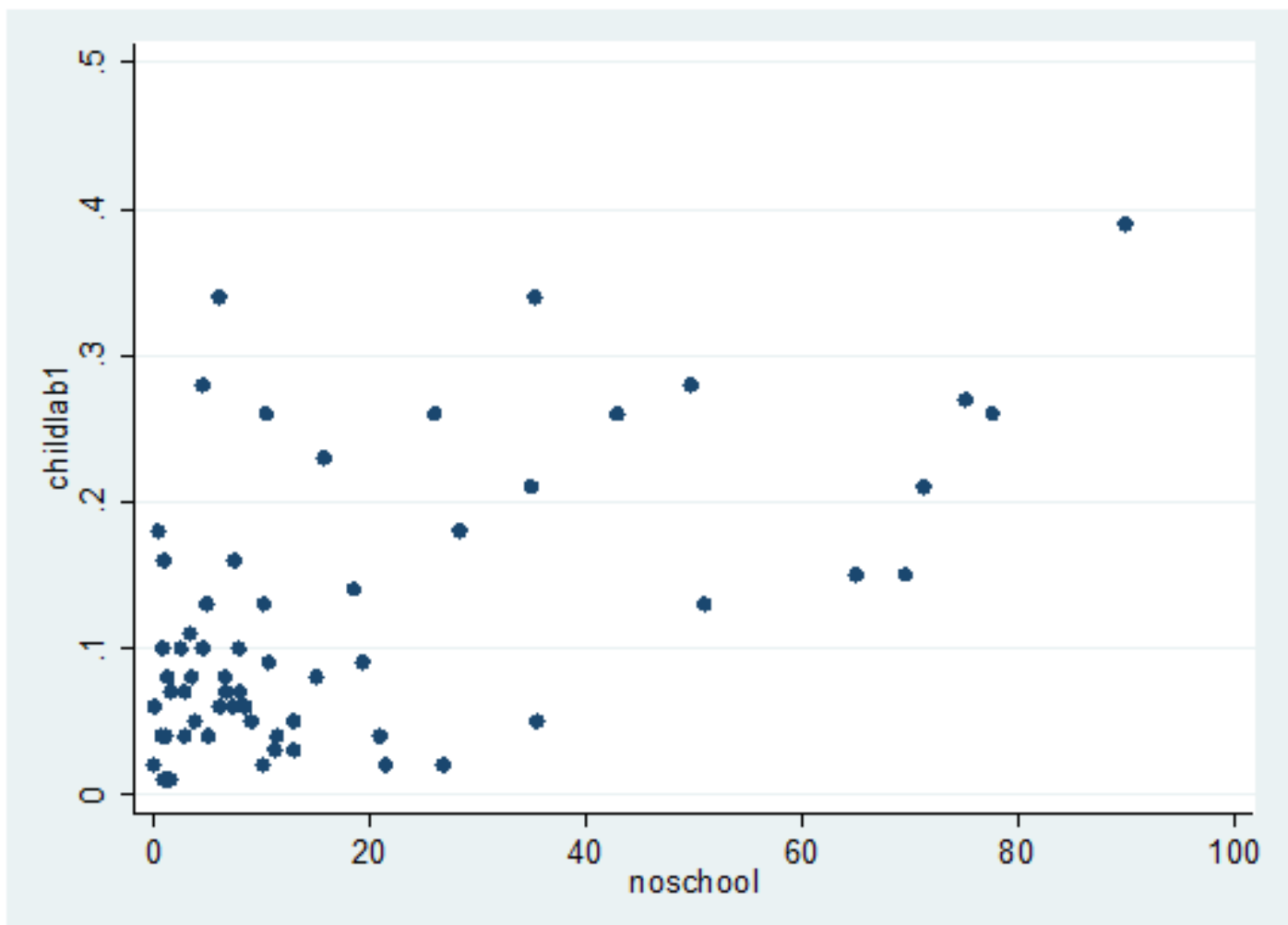


Figure 2. Correlation between child labour and per-capita GDP

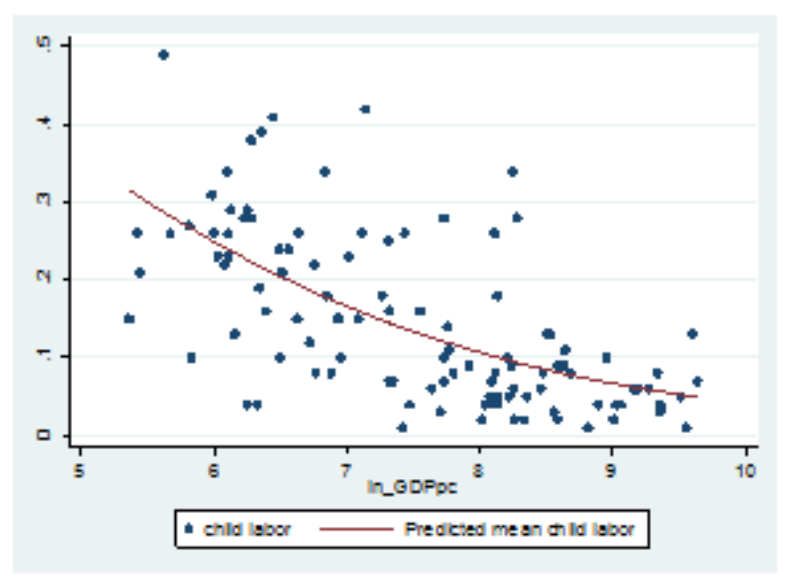

Note $\mathrm{y}=$ child labour, $\mathrm{x}=$ per-capita GDP

Figure 3. FDI into African regions

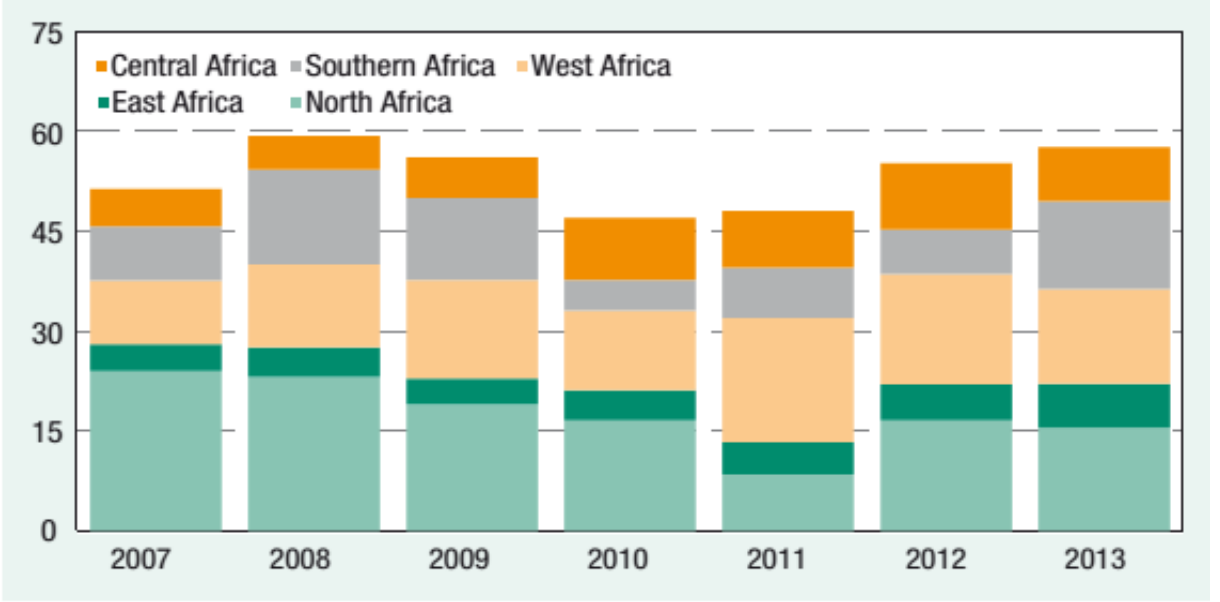

Source: UNCTAD, WIR (2014) 